\title{
Pengaruh Likopen terhadap Penurunan Aktivitas Mitogen-Activated Protein Kinase (MAPK) dan Ekspresi Endothelin-1 (ET-1) pada Kultur Huvecs yang Dipapar Leptin
}

\author{
Heni Fatmawati ${ }^{\left.{ }^{*}\right)}$, Satuman ${ }^{2)}$, Ahmad Rudijanto $^{3)}$, dan Muhammad Rasjad Indra2) \\ 1)Laboraturium Biomedik, Fakultas Kedokteran, Universitas Jember, Jalan Kalimantan 23 Jember 68121 \\ 2)Laboraturium IImu Faal, Fakultas Kedokteran, Universitas Brawijaya, Jalan Veteran Malang 65145 \\ 3)Bagian penyakit dalam Rumah Sakit Saiful Anwar/Fakultas Kedokteran, Universitas Brawijaya, \\ Jalan Veteran Malang 65145
}

Diterima 12-03-2010 Disetujui 06-12-2010

\begin{abstract}
The effect of obesity on vascular function is mediated by hormon leptin. Leptin has been proved to increase oxidative stress in endothelial cell. The previous study has proven that leptin caused the endothelial dysfunction as a step of the atherogenesis. Lycopene, an antioxidant, is presumed having the ability to block the atherogenesis mechanism, which is stimulated a proinflamatory cytokine and adhesion molecules by MAPK and transcription factor ET-1. Therefore, the aim of this research was to prove and to determine whether lycopene could decrease the MAPK and ET-1 expression in Human Umbillical Vein Endothelial Cells (HUVECs) culture induced by $500 \mathrm{ng} / \mathrm{ml}$ leptin. In vitro study used primary culture of the HUVECs were devided in to 7 groups, there were (1) $0 \mathrm{ng} / \mathrm{ml} \mathrm{leptin}$ and $0 \mathrm{iM}$ lycopene, (2) induced by $500 \mathrm{ng} / \mathrm{ml}$ leptin for 12 hours, (3) induced by leptin and lycopene with concentration 10; 25; 40; 55 and 75 iM for 12 hours. Then the identification of MAPK was applied by using imunocytochemistry compared with ELISA procedure on cell endothel culture lysate and ET-1 expression was measured by using RT PCR. It was showed that lycopene 10-25 iM decreased MAPK and ET-1 expression significantly in HUVECs culture induced by leptin $500 \mathrm{ng} / \mathrm{ml}$. Leptin was increased ERK1/2 MAPK and ET-1 expression in HUVECs culture and can decrease by lycopene. Optimum dose of lycopene is 10-25 iM.
\end{abstract}

Keywords: endothelin-1 (ET-1), leptin, lycopene, mitogen-activated protein kinase (MAPK), obesity

\section{PENDAHULUAN}

Nutrisi (gizi) yang baik merupakan kebutuhan vital untuk kesehatan, pertumbuhan dan perkembangan serta pencegahan penyakit. Zat bioaktif pada makanan bisa mempengaruhi ekspresi gen baik secara langsung maupun tidak langsung. Dalam hal ini termasuk juga interaksi antara komponen bioaktif dari makanan dengan sitesis protein, degradasi protein, dan modifikasi protein yang keseluruhannya bermuara pada metabolisme sel (Kaput, 2004). Interaksi antara nutrisi dengan genomik (nutrigenomik) merupakan kajian yang sangat menarik karena masih sedikit data penelitian yang mengungkap hal tersebut (Suarez, 2005).

Obesitas menjadi masalah kesehatan masyarakat di dunia. Data tentang obesitas di Indonesia berdasarkan survei nasional yang dilakukan pada tahun 1996/1997 di ibukota seluruh propinsi Indonesia menunjukkan bahwa $8,1 \%$ penduduk laki-laki dewasa ( $>=18$ tahun) mengalami overweight (BMI 25-27) dan

\footnotetext{
*Telp: +628179621176

Email: fatmawatiheni@ymail.com
}

6,8\% mengalami obesitas, $10,5 \%$ penduduk wanita dewasa mengalami overweight dan $13,5 \%$ mengalami obesitas. Pada kelompok umur 40-49 tahun overweight maupun obesitas mencapai puncaknya yaitu masingmasing $24,4 \%$ dan $23 \%$ pada laki-laki dan $30,4 \%$ dan $43 \%$ pada wanita (Depkes RI, 2004). Obesitas khususnya obesitas viseral selama ini diketahui sebagai penyebab utama meningkatnya angka kesakitan dan kematian.

Penelitian terdahulu membuktikan bahwa terdapat hubungan antara obesitas dan aterosklerosis. Zat yang merangsang inflamasi maupun protein dihasilkan sel radang terlibat secara langsung sejak awal hingga proses terjadinya komplikasi dari aterosklerosis. Fase awal kunci pembentukan aterosklerossis (atherogenesis) dimulai dari penumpukan lekosit terutama monosit dan $\mathrm{T}$ lymphosit pada dinding pembuluh darah yang dipicu oleh adipokine (sitokin adiposit) yaitu leptin. Hasil penelitian menunjukkan bahwa terjadi peningkatan leptin pada kondisi obesitas (David et al., 2005). 
Pada kondisi obesitas, sekresi leptin di tubuh sangat berlebih. Leptin merupakan protein yang dikode oleh gen $\mathrm{Ob}$, yang diproduksi terutama oleh adiposit (Indra, 2006). Peradangan terjadi karena leptin mengaktifkan faktor transkripsi Nuclear Factor Kappa Beta (NF-kB melalui jalur mitogen-activated protein kinase (MAPK) dan NF-kB yang teraktifasi akan menginduksi terbentuknya protein-protein sistim imun dan molekul/ zat perantara yang pada akhirnya meningkatkan progresifitas aterosklerosis atau memicu ruptur dari plak aterosklerosis dan mengakibatkan pembuntuan arteri koroner (infark miokard), pembuluh darah otak (stroke) dan lain-lain. Mengingat keradangan menjadi faktor utama dari patogenesis aterosklerosis maka NF-kB merupakan faktor molekuler yang tepat untuk pencegahan dan pengobatan aterosklerosis (David et al., 2005).

Indonesia sebagai negara tropis mempunyai keragaman nutrisi yang mempunyai potensi besar untuk dikembangkan dalam dunia pengobatan. Likopen adalah antioksidan kuat dari golongan karotenoid dengan kandungan terbanyak terdapat pada buah tomat dan produk olahannya. Potensinya sebagai antioksidan akan meredam spesies oksigen reaktif yang akan mengurangi kerusakan oksidatif pada lipid (termasuk lipoprotein dan lipid membran), protein dan DNA serta mencegah oksidasi dari kolesterol low-density lipoprotein (LDL) sehingga akan menghambat perkembangan aterosklerosis. Hasil penelitian menunjukkan bahwa likopen dapat digunakan sebagai antioksidan, menghambat oksidasi LDL, menghambat adesi, invasi dan migrasi sel hepatoma secara in vitro dan menghambat IGF-1 pada sel epitel prostat (Hwang \& Lee 2006; Ute et al., 2003; Balz 2003). Tetapi sampai saat ini belum diketahui peranan likopen terhadap dampak yang disebabkan oleh obesitas dan belum diketahui peranan likopen terhadap nutrigenomik.

Hasil penelitian pendahuluan membuktikan bahwa pemberian pasta tomat pada tikus (Rattus novergicus) strain Wistar mampu menurunkan pembentukan sel busa (foam cell) pada pembuluh darah dan menurunkan kadar F2-Isoprostane (Handayani, 2006). Karena itu diperlukan kajian lebih lanjut untuk mengetahui apakah likopen juga berpengaruh pada aktifasi MAPK dan transkripsi gen yang dihasilkannya. Transkripsi gen yang akan diamati adalah mRNA ET-1.

\section{BAHAN DAN METODE}

Penelitian ini menggunakan desain eksperimen murni (true eksperimental) yang dikerjakan di laboratorium secara invitro dengan menggunakan rancangan percobaan Randomized Group Only Design. Penelitian ini dilakukan melalui dua tahap. Tahap I mengamati pengaruh likopen terhadap aktivasi NF-êB yang berperan di dalam aterosklerosis pada sel endotel yang dipapar oleh leptin. Tahap II mengamati pengaruh likopen dosis optimal terhadap faktor transkripsi mRNA ET-1 yang berperan di dalam aterosklerosis.

Kultur Sel Endotel Manusia (HUVECs). Metode kultur ini merujuk Bouloumie et al., (1999). Umbilicus dibersihkan dari jaringan dan sisa darah dengan kasa steril yang dibasahi dengan alkohol $70 \%$. Masingmasing ujung umbilicus dipotong secara transversal sehingga terlihat adanya dua pembuluh arteri dan vena dimana pembuluh vena memiliki dinding yang lebih tebal, besar dan elastis. Kanul dimasukkan salah satu ujung pembuluh vena kira-kira $1 \mathrm{~cm}$ lalu diikat erat dengan benang. Pembuluh vena dicuci dengan PBS A melalui kanul yang telah terpasang dengan menggunakan spuit 20 ml Lakukan 2-3 kali. Setelah bersih, ikat ujung umbilicus yang lain dengan ikatan kuat atau diklem. Larutan Collagenase tipe II dimasukkan dan spuit dibiarkan menancap pada kanul. Selanjutnya umbilicus dihangatkan dengan cara didekap kedua belah tangan selama 10 menit. Larutan Collagenase yang mengandung endotel dikeluarkan dari umbilicus dengan cara menyedot malalui spuit yang terpasang pada ujung kanul. Kemudian Collagenase tersebut dimasukkan tabung sentrifuse steril $15 \mathrm{ml}$ Umbilicus dibilas dengan $8 \mathrm{ml}$ arutan PBS-A untuk membilas sel endotel yang tersisa. Kemudian larutan dibilas kembali yang ditambahkan ke tabung centrifuge yang berisi larutan Collagenase. Larutan yang mengandung endotel disentrifugasi dengan kecepatan $95 \mathrm{~g}$ selama 8 menit sehingga diperoleh pellet yang berisi sel endotel. Supernatan dibuang kemudian ditambahkan $4 \mathrm{ml}$ edium kultur pada pellet dan diresuspensi dengan cara pipeting sehingga sel endotel terpisah. Larutan dipindahkan ke dalam flask $25 \mathrm{~cm}^{2}$ yang telah dilapisi larutan Gelatin 0,2\% kemudian dimasukkan dalam inkubator $\mathrm{CO}_{2} 5 \%$ pada suhu $37^{\circ} \mathrm{C}$ selama 30 menit. 
Perlakuan Induksi Leptin pada HUVECs. tode ini bertujuan untuk membuat model sindroma metabolik pada sel kultur endotel secara in vitro. Metode induksi leptin pada sel kultur endotel manusia merujuk pada Spritzer et al., (2001). Sel endotel diinkubasi dengan $500 \mu \mathrm{g} / \mathrm{ml}$ uman recombinant leptin (hiperleptin). Sel endotel diinkubasi $37^{\circ} \mathrm{C}$ selama 6 jam.

Perlakuan Likopen (HyperChem) pada Sel Endotel. tode perlakuan likopen ini merujuk pada Hwang and Lee (2006). Likopen diperoleh dari HyperChem Singapura. Sel endotel yang sudah monolayer diinkubasi dengan likopen dengan beberapa dosis. Dosis yang diberikan adalah sebagai berikut kontrol, $10 \mathrm{mM}, 25$, 40, 55 dan $70 \mathrm{mM}$. Metode pemberian likopen yaitu likopen diperlakukan setelah sel diinkubasi dengan leptin selama 6 jam.

Pengukuran Kadar Protein Intrasel MAPK dengan ELISA. Pengukuran kadar MAPK dilakukan secara kualitatif dengan menggunakan prosedur dalam Human ERK1/2 MAPKAssay Kit (Assay Design, USA). Selanjutnya ditentukan nilai absorbansi standar serta nilai absorbansi sampel menggunakan ELISA readers pada OD $492 \mathrm{~nm}$.

Identifikasi MAPK dengan Imunositokimia. Metode ini merujuk Melotti et al., 2001). Kultur sel endotel masing-masing perlakuan difiksasi dengan formalin 10\% (v/v) dalam PBS pH 7,4 selama 20 menit. Sel dicuci dengan PBS pH 7,4 sebanyak tiga kali selama masing-masing 5 menit. Sel ditetesi dengan $0,02 \%(\mathrm{w} / \mathrm{v})$ sodium azide. Sel ditetesi dengan larutan $\mathrm{H}_{2} \mathrm{O}_{2}$ dalam PBS selama 10 menit. Sel ditetesi dengan blocking serum $5 \%$ FBS yang mengandung Triton-X $0,25 \%$ selama 1 jam. Sel dicuci dengan PBS. Inkubasi antibodi primer dalam serum $1: 500$ selama 24 jam. Sel disimpan pada suhu $4^{\circ} \mathrm{C}$. Sel dikeluarkan pada suhu ruang selama 15 menit. Jaringan dicuci dengan PBS 3 kali selama masing-masing 5 menit. Sel diinkubasi dengan antibodi sekunder anti rabbit 1:500 selama 1 jam pada suhu ruang. Sel dicuci dengan PBS 3 kali selama masing-masing 5 menit. Sel ditetesi dengan SA-HRP selama 40 menit kemudian dicuci dengan PBS 3 kali selama masing-masing 5 menit. Sel ditetesi dengan Diamino Benzidine (DAB) dalam buffer DAB. Sel ditetesi dengan counterstain Mayer hematoxilen selama 10 menit. Sel dicuci dengan air kran kemudian dicuci dengan aquades selama 10 menit. Sel diletakkan pada object glass, ditetesi dengan entellan kemudian diamati menggunakan mikroskop. Ekspresi MAPK diamati sebagai warna coklat, dan kerapatan warna merupakan indikator peningkatan ekspresi yang diamati oleh peneliti dan 2 peneliti lain yang independen.

Isolasi mRNA pada Sel Kultur dan RTPCR.Pada masing-masing perlakuan dilakukan isolasi mRNA. Media dibuang dan sel dicuci dengan 5-10 ml PBS dingin. Buffer PBS dibuang dan sel dilisiskan dengan reagen monophasic lysis (ML). Suspensi sel dipindah ke tabung Falcon dan dihomogenisasi selama 15-30 menit pada suhu ruang. Suspensi diinkubasi 5 menit pada suhu ruang ditambahkan 0,2 $\mathrm{ml}$ kloroform / $\mathrm{ml}$ reagen ML. Suspensi diputar $3.000 \mathrm{~g}, 15$ menit, $4^{\circ} \mathrm{C}$. Supernatan dipindah pada tabung baru. Presipitan RNA ditambahkan dengan 0,25 volume isopropanol dan 0,25 volume presipitan RNA dalam $1 \mathrm{ml}$ reagen ML dan dihomogenasi suhu ruang selama 10 menit. Suspensi diputar $3.000 \mathrm{~g}$, 10 menit, $4^{\circ} \mathrm{C}$. Supernatan dibuang dan pelet dicuci dengan $75 \%$ etanol. Pelet dikeringkan dan ditambahkan dengan diethylpyrocarbonate (DEPC). Simpan RNA pada $-30^{\circ} \mathrm{C}$ (Montague et al., 1997). Sampel mRNA selanjutnya dilakukan Reverse transcription polymerase chain reaction (RT-PCR). RT-PCR digunakan untuk merubah mRNA menjadi cDNA.

RT PCR. Primer yang digunakan adalah Primer ET-1 merujuk Peter et al., (2002) (human dan murine) sense, 5'-GCTGGTGGAGGGAAGAAAAC-3' dan antisense, 5'-CACCACGGGGCTCTGTAGTC-3'. Primer tersebut diambil dari gen ET-1. Sampel diamplifikasi melalui PCR dengan $94^{\circ} \mathrm{C}, 58^{\circ} \mathrm{C}, 72^{\circ} \mathrm{C}$ selama 30 menit setiap siklus dan diulang sebanyak 30 siklus). Produk PCR diseparasi dengan elektroforesis $2 \%$ agarosa. Evaluasi sel yang mengekspresikan ET-1 dikuantifikasi dari densitas warna band pada gel agarosa menggunakan process imaging analysis sesuai instruksi yang terdapat pada software corel draw paint 12.

Analisis Data. Data hasil penelitian akan disajikan dalam mean $\pm S D$. Data penelitian merupakan data kuantitatif dan kualitatif. Semua data penelitian akan dianalisis dengan menggunakan software SPSS versi 14. Untuk data kuantitatif, analisis menggunakan oneway ANOVA dilanjutkan dengan uji Tukey untuk mengetahui perbedaan antar variabel pada masingmasing perlakuan. 


\section{HASIL DAN PEMBAHASAN}

Metode pengukuran kadar protein MAPK menggunakan Human ERK1/2 MAPK ELISA Kit. Pada Tabel 1 dapat dilihat bahwa perlakuan $500 \mathrm{ng} / \mathrm{ml}$ leptin $(18,115 \pm 1,823)$ dapat meningkatkan aktivitas MAPK intrasel secara signifikan dibandingkan dengan kontrol negatif $(9,965 \pm 0,194)$.

Aktivitas MAPK turun dengan pemberian likopen $10 \mu \mathrm{M}$ dan secara signifikan pada likopen dosis $25 \mu \mathrm{M}$ (L500Li25) jika dibandingkan dengan kontrol positif pada sel endotel yang dipapar dengan leptin. Sedangkan pada likopen $40 \mu \mathrm{M}$ dan $55 \mu \mathrm{M}$, aktivitas MAPK meningkat kembali dibandingkan dengan kontrol negatif walaupun aktivitas MAPK dengan pemberian likopen $70 \mu \mathrm{M}$ kembali turun dan tidak berbeda nyata dengan kelompok normal (kontrol negatif).

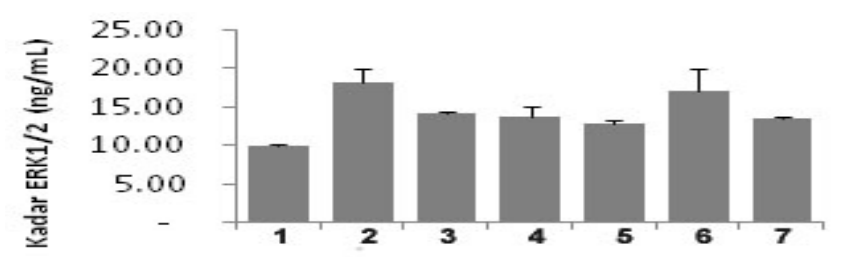

Keterangan: Kelp 1 : Leptin 0 ng/ml (K-); Kelp 2 : Leptin 500 ng/ml $(\mathrm{K}+)$; Kelp 3 : Leptin $500 \mathrm{ng} / \mathrm{ml}+$ Likopen $10 \mu \mathrm{M}$ (L500Li10); Kelp 4 : Leptin $500 \mathrm{ng} / \mathrm{ml}+$ Likopen $25 \mu \mathrm{M}$ (L500Li25); Kelp 5 : Leptin $500 \mathrm{ng} / \mathrm{ml}+$ likopen $40 \mu \mathrm{M}$ (L500Li40); Kelp 6 : Leptin $500 \mathrm{ng} / \mathrm{ml}+$ likopen $55 \mu \mathrm{M}$ (L500Li55) dan Kelp 7 : leptin $500 \mathrm{ng} / \mathrm{ml}+$ likopen 70 HM (L500Li70).

Gambar 1. Diagram batang kadar protein intrasel ERK1/2MAPK pada HUVEC yang telah diinduksi leptin dan dipapar beberapa dosis likopen

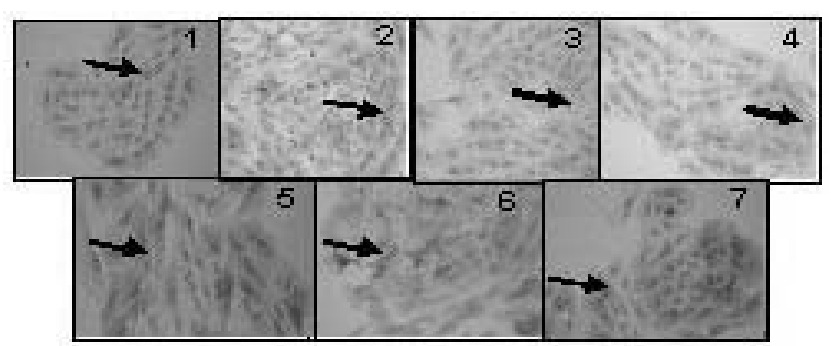

Gambar 2. Identifikasi protein intrasel ERK1/2MAPK pada HUVEC yang telah diinduksi leptin dan dipapar beberapa dosis likopen secara imunohistokimia

Tabel 1. Hasil analisis statistik kadar protein intrasel ERK1/2MAPK pada HUVEC yang telah diinduksi leptin dan dipapar beberapa dosis likopen

\begin{tabular}{cc}
\hline Kelompok & $\begin{array}{c}\text { Kadar MAPK }(\mathrm{pg} / \mathrm{ml}) \\
(\text { Mean } \pm S D)^{*}\end{array}$ \\
\hline Kontrol negatif & $9,965 \pm 0,194^{\mathrm{a}}$ \\
Kontrol positif & $18,115 \pm 1,823^{\mathrm{d}}$ \\
L500Li10 & $14,224 \pm 0,296^{\mathrm{bcd}}$ \\
L500Li25 & $12,795 \pm 1,452^{\mathrm{ab}}$ \\
L500Li40 & $13,659 \pm 1,452^{\mathrm{abc}}$ \\
L500Li55 & $16,993 \pm 3,054^{\mathrm{cd}}$ \\
L500Li70 & $13,448 \pm 0,235^{\mathrm{abc}}$
\end{tabular}

Keterangan: notasi yang berbeda menunjukkan perbedaan yang nyata $(a ́$ 0,05)
Identifikasi Ekspresi ET-1 menggunakan RT PCR. Hasil elektroforesis ET-1 menggunakan metode RT-PCR didapatkan gen cDNAET-1 dengan ukuran 101 bp (Gambar 3).

Berdasarkan data Tabel 2, terdapat peningkatan ekspresi mRNA ET-1 pada kelompok yang diberi leptin (kontrol positif). Pemberian likopen 10-25 mM menurunkan ekspresi mRNA ET-1 secara signifikan dibandingkan dengan kontrol positif maupun negatif. Sedangkan likopen pada konsentrasi mulai $40 \mathrm{mM}$ menunjukkan peningkatan ekspresi mRNA ET-1 meskipun tidak berbeda nyata dengan kelompok kontrol positif dan negatif. Dari hasil tersebut menunjukkan bahwa likopen 10-25 mM merupakan dosis optimum dalam menurunkan ekspresi gen ET-1.

Enzim MAPK merupakan salah satu anggota superfamili MAP serin/threonin protein kinase, selain ERK1 (extracellular signal-regulated protein kinase atau p44MAPK), ERK2 (p42MAPK), dan JNK (c-Jun $\mathrm{NH}_{2}$ terminal kinase) atau SAPK (stress-activated protein kinase) (Evans et al., 2002; Thannickal \& Fanburg, 2000). Aktifasi enzim MAPK diketahui diinduksi oleh berbagai stimulus stress endogen maupun eksogen, antara lain hiperglikemia, ROS, stress oksidatif, stress osmotik, sitokin-sitokin proinflamasi, heat shock dan radiasi sinar ultra violet (Droge, 2001; Evans et al., 2002).

Pengukuran aktifitas MAPK di sel kultur HUVECs pada penelitian ini dilakukan dengan mengamati ekspresi MAPK yang terfosforilasi. Hasil penelitian menunjukkan bahwa leptin dapat menginduksi aktivitas

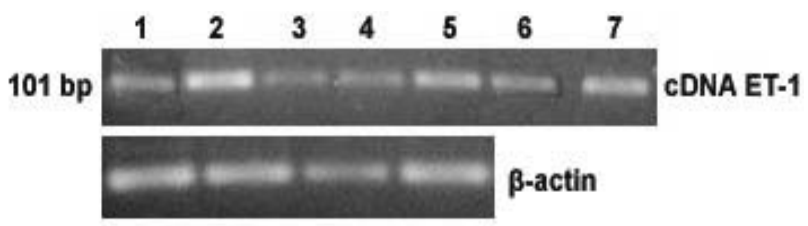

Gambar 3. Hasil RT-PCR ET-1 pada HUVEC yang telah diinduksi leptin dan dipapar beberapa dosis likopen. Didapatkan cDNA ET-1 dengan ukuran $101 \mathrm{bp}$

Tabel 2. Persentase jumlah sel yang mengekspresikan gen ET-1 berdasarkan densitas warna elektroforesis pada HUVEC yang telah diinduksi leptin dan dipapar beberapa dosis likopen

\begin{tabular}{cc}
\hline Kelompok & Ekspresi gen ET-1 Mean \pm SD $^{*}$ \\
\hline Kontrol negatif & $161,93 \pm 14,04^{\mathrm{b}}$ \\
Kontrol positif & $171,83 \pm 4,39^{\mathrm{b}}$ \\
Likopen $10 \mu \mathrm{M}$ & $125,58 \pm 10,34^{\mathrm{a}}$ \\
Likopen $25 \mu \mathrm{M}$ & $119,82 \pm 13,04^{\mathrm{a}}$ \\
Likopen $40 \mu \mathrm{M}$ & $135,72 \pm 15,16^{\mathrm{ab}}$ \\
Likopen $55 \mu \mathrm{M}$ & $138,58 \pm 17,20^{\mathrm{ab}}$ \\
Likopen $70 \mu \mathrm{M}$ & $136,03 \pm 13,24^{\mathrm{ab}}$ \\
\hline
\end{tabular}

Keterangan: Notasi yang berbeda menunjukkan berbeda nyata (á 0,05) 
MAPK seperti pada Tabel 1. Leptin mampu meningkatkan kadar protein intrasel MAPK pada kelompok kontrol positif secara nyata $(p<0,05)$. Aktivitas MAPK turun dengan pemberian likopen $10 \mu \mathrm{M}$ dan secara signifikan pada likopen dosis $25 \mu \mathrm{M}$ (L500Li25) jika dibandingkan dengan kontrol positif pada sel endotel yang dipapar dengan leptin. Sedangkan pada likopen $40 \mu \mathrm{M}$ dan $55 \mathrm{iM}$, aktivitas MAPK meningkat kembali dibandingkan dengan kontrol negatif walaupun aktivitas MAPK dengan pemberian likopen $70 \mu \mathrm{M}$ kembali turun. Analisis statistik lebih lanjut menunjukkan dosis optimum dalam menghambat aktivitas MAPK adalah 10-25 $\mu$ M. Peningkatan aktifitas enzim p38 MAPK pada paparan leptin diduga akibat peningkatan ROS. Menurut Evans et al., (2002), ROS dapat mengaktifkan ASK1 (apoptosis signal-regulating kinase) yang merupakan sensor adanya stress oksidatif. ASK1 mengaktifkan MKK3/6 (MAPK kinase) yang selanjutnya memfosforilasi enzim p38 MAPK pada residu threonin180 dan tirosin182 sehingga enzim p38 MAPK menjadi aktif. Enzim p38 MAPK yang teraktifasi selanjutnya dapat memfosforilasi actifator transcription factors (ATF-2) yang menstimulasi transkripsi gen. ASK1 juga dapat diaktifasi oleh sitokin-sitokin proinflamasi (Evans et al., 2002; Roux \& Blenis, 2004).

Dugaan mekanisme induksi leptin pada sel endotel adalah leptin ditangkap oleh reseptor leptin Ob-Rb pada sel. Selanjutnya leptin mengaktivasi AMPK yang merupakan enzim fuel sensing yang akan teraktivasi apabila terjadi peningkatan rasio AMP/ATP. Aktivasi fosforilasi AMPK menghambat aktivitas ACC yang selanjutnya menghambat sintesis Malonyl-CoA, mengaktifkan CPT 1 (enzim kunci dalam oksidasi asam lemak) (Minokoshi \& Khan, 2003). Hal ini mengakibatkan peningkatan oksidasi asam lemak di mitokondria sehingga meningkatkan produksi ROS berupa superoksida mitokondrioal. Menurut Epstein et al., (2003), ROS selanjutnya mengaktifkan faktor transkripsi NF-kB. ROS menginisiasi cascade serin kemudian menyebabkan terjadinya fosforilasi IkB (penambahan fosfat pada lkB). Selanjutnya ikatan NFkB-lkB terlepas dan heterodimer NF-kB (p50 dan p65) bebas. Terlepasnya ikatan ini menyebabkan NF-kB berpindah atau bertranslokasi ke dalam inti sel (nukleus) secara otomatis. Aktivasi NF-kB menginduksi transkripsi inflammatori gen diantaranya sitokin proinflamatori TNFa dan beberapa molekul adesi seperti ICAM-1 maupun VCAM.
Aktifasi p38 MAPK mempengaruhi beberapa proses seluler, antara lain pertumbuhan sel dan apoptosis, inflamasi, serta respon jaringan spesifik akibat stres melalui regulasi ekspresi gen. Enzim p38 MAPK juga meregulasi serin kinase dan mengaktifasi faktor transkripsi yang menyebabkan berbagai efek patologis (Evans et al., 2002). Pada penelitian ini, adanya penurunan aktifitas MAPK setelah pemberian likopen, menunjukkan terdapat peran likopen terhadap hambatan pada aktifitas MAPK. Dalam hal ini didapatkan dosis optimum adalah 10-25 ì. Hal ini membuktikan bahwa likopen sebagai antioksidan merupakan scavenger ROS yang meningkat akibat paparan leptin, disamping juga menghambat terjadinya fosforilase MAPK. Hambatan fosforilase ini menyebabkan penurunan aktivitas NF-êB sehingga transkripsi gen inflamatori serta sintesis beberapa sitokin proinflamasi seperti TNF, IL-1, IL-2, IL-6 dan mediator inflamasi VCAM-1 dan ICAM-1 menjadi turun.

Menurut Quehenberger et al., (2002), leptin dengan konsentrasi $25 \mathrm{ng} / \mathrm{ml}$ dapat mengakibatkan terjadinya disfungsi pada kultur sel endotel. Disfungsi endotel yang dimulai dengan proses inflamasi, diawali dengan aktivasi MAPK dan faktor transkripsi NF-kB oleh ROS sebagai akibat induksi leptin. Fosforilase MAPK selanjutnya akan mengaktivasi NF-kB dan merangsang transkripsi gen inflamatori serta menyebabkan sintesis beberapa sitokin proinflamasi seperti TNFa, IL-1, IL-2, IL-6 dan mediator inflamasi VCAM-1 dan ET-1. Transkripsi gen inflamatori dapat terjadi pada sel endotel, otot polos dan makrofag. Inflamasi sendiri menjadi faktor utama dari patogenesis terjadinya berbagai penyakit degeneratif (Barnes \& Karin, 1997; Collins et al., 2001; Jacobson \& Mc. Carthy, 2002).

Endotelin-1 ditemukan pada sel endotel, sel otot polos pembuluh darah, leukosit dan cardiomyociytes. ET-1 mempunyai efek vasokonstriktor dan efek mitogenik, menstimulasi produksi growth factor. Pada aterosklerosis, infark miokard dan gagal ginjal level ET-1 meningkat baik pada plasma maupun pada jaringan. Diet tinggi lemak, memicu timbulnya disfungsi endotel dan dihubungkan dengan tingginya level ET-1 pada plasma dan pada jaringan. Peningkatan pelepasan ET-1 menstimulasi sintesis beragam molekul adesi seperti VCAM dan ICAM-1 yang mengarah pada terjadinya aterogenesis (Barrata et al., 2002). 
Hasil penelitian terhadap ekspresi ET-1 menunjukkan terdapat penurunan ekspresi ET-1 pada kultur endotel yang dipapar leptin setelah pemberian likopen. Dari hasil analisis statistik, dosis optimum likopen menurunkan ekspresi ET-1 adalah 10-25 ì. Sekresi ET-1 yang diinduksi oleh leptin pada HUVEC mungkin berkontribusi terhadap resiko penyakit kardiovaskuler pada individu obes. Paparan leptin menyebabkan peningkatan ekspresi ET-1. Peningkatan vasokonstriktor ET-1 akan menyebabkan kondisi ketidakseimbangan terhadap vasodilator yang dihasilkan oleh endotel. Ketidakseimbangan ini merupakan salah satu tanda disfungsi endotel. Penelitian lain sebelumnya juga membuktikan bahwa ET-1 menyebabkan perkembangan dari aterosklerosis, seperti proliferasi fibroblast dan sel otot polos. (Quehenberger et al., 2002). Likopen sebagai scavanger ROS, menyebabkan ROS tidak bersifat reaktif lagi. ROS yang tidak reaktif tidak akan mampu lagi mengaktifasi MAPK sehingga transkripsi gen oleh NF-kB terhadap vasokonstriktor ET-1 turun (Lawrence, 2004). Penurunan ekspresi vasokonstriktor ET-1 pada endotel akan menghambat perkembangan proses aterogenesis selanjutnya.

\section{KESIMPULAN}

Berdasarkan hasil penelitian ini dapat disimpulkan bahwa likopen dapat menghambat peningkatan kadar MAPK dan ekspresi gen ET-1 pada sel endotel akibat paparan leptin dengan dosis optimum likopen yaitu 10-25 ì M.

\section{UCAPAN TERIMA KASIH}

Terima kasih kami sampaikan kepada Departemen Pendidikan Tinggi melalui Lembaga Penelitian dan Pengembangan Program Hibah Bersaing dengan Nomor Kontrak 320/SP2H/PP/DP2M/V/2009 yang telah memberikan dana penelitian. Terima kasih juga kepada Dr.dr.Budi Siswanto, SpOG dan para partisipan atas kerjasamanya.

\section{DAFTAR PUSTAKA}

Barrata, M. 2002. Leptin-from a signal of adiposity to a hormone mediator in peripheral tissues. Med Sci Monit 8: RA 282-292.

Bouloumie, A. Marumo, T., Lafontan, M. \& Busse, R. 1999. Leptin induces oxidative stress in human endothelial cells. FASEB Journal 13: 1231-1238.

David, C.W., Lau., Bikramjit, D., Hongyun, Y., Paul, E.S. \& Subodh, V. 2005. Adipokines:molecular links between obesity and atherosclerosis. Am. Journal Physiol Heart Circ Physiol 288: H2031-H2041.

Departemen Kesehatan RI. 2004. Kecenderungan Masalah Gizi dan Tantangan di Masa Datang. Jakarta.

Droge, W. 2002. Free Radicals in the Physiological Control of Cell Function. Physiol Rev 82: 47-95.

Epstein, F.H. 2003. Nuclear Factor Kappa beta a Pivotal transcription factor in chronic inflamatory Disease. NEJM 363(15): 1066-1071.

Evans, J.L., Goldfine, I.D., Maddux, B.A. \& Grodsky, G.M. 2002. Oxidative Stress and Stress-Activated Signaling Pathways: A Unifying Hypothesis of Type 2 Diabetes. Endocrine Reviews 23(5): 599-622.

Frei, B. 2003. Reactive Oxygen Species and Antioxidant Vitamins. The Linus Pauling Institute.

Handayani, D. 2006. Pengaruh pasta tomat terhadap sel busa (foam cell) pada tikus diet aterogenik. Journal Kedokteran Universitas Brawijaya III: 7-14.

Hwang, H. \& Lee, H.J. 2006. Inhibitory Effects of Likopen on the Adhesion, Invasion, and Migration of SK-Hep1 Human Hepatoma Cells. The Society for Experimental Biology and Medicine.

Indra, M.R. 2006. Adiposit, obesitas dan masalah kesehatan global di era millenium. Edisi Pertama. Penerbit. Lab. IImu Faal FK. UNIBRAW. Malang. ISBN : 979-25-9010-2.

Kaput, J. 2004. Diet-disease gene interaction. Nutrition. 20: 2631.

Lawrence, G.S. 2004. Implikasi Klinis Disfungsi Endotel dan Radikal Bebas. Journal Med Nus 25: 94-102.

Minokoshi, Y. \& Kahn, B.B. 2003. Role of AMP-Activated Protein Kinase in Leptin-induced Fatty Acid Oxidation in Muscle. Biochemical Society Transactions 31, part 1.

Melotti, P.E., Nicolis, A., Tamanini, R., Rolfini, A., Pavirani. \& Cabrini. G. 2001. Activation of NF-kB mediates ICAM-1 induction in respiratory cells exposed to an adenovirusderived vector. Gene Theraphy 8(18): 1436-1442.

Montague, C.T., Prins, J.B., Sanders, L., Digby, J.E. \& Rahilly, S. 1997. Depot and sex-specific differences in human leptin mRNA expression: implications for the control of regional fat diatribution. Diabetes 46: 342-347.

Quehenberger, P., Exner, M., Sunder-Plassmann, R., Ruzicka, K., Bieglmayer, C., Endler, G., Muellner, C., Speiser, W.\& Wagner. O. 2001. Leptin Induces Endothelin1 in Endothelial Cells In Vitro. Circ Res 90: 711-718.

Roux, P.P. \& Blenis, J. 2004. ERK and p38 MAPK-Activated Protein Kinases: a Family of Protein Kinases with Diverse Biological Functions. Microbiology and Molecular Biology Reviews 68(2): 320-344

Suarez, L. 2005. Nutritional Genomics:Customizing Diet Plans According to Genetic Makeup. Diabetic microvascular complications today. Issues in Diabetes.

Thannickal, V.J. \& Fanburg, B.L. 2000. Reactive oxygen species in cell signaling. Am Journal Physiol Lung Cell Mol Physiol 279: L1005-1028.

Ute, C.O., Estibaliz, O.M., Ana, M.C., Jason, P.E., Albert, van der V., Giuseppe, V.C.E.C \& Lester, P. 2003. Likopen inhibits the growth of normal human prostate epithelial cells in vitro. Biochemichal and Molecular Action of Nutrients. 